\title{
KEGIATAN SENAM OTAK ANAK USIA DINI
}

\author{
Yolanda Dwi Putri \\ Rivda Yetti \\ Pendidikan Guru Pendidikan Anak Usia Dini Fakultas Ilmu Pendidikan \\ Universitas Negeri Padang \\ Email: Yolandadwiputri27@gmail.com
}

Received March 2019, Accepted April 2019, Published April 2019

\begin{abstract}
Brain exercise has many benefits, especially to balance the child's brain and left, though brain gym activities can foster the spirit of learning children. This study describe brain gym activities carried out in the primagama padang creative kindergarden \& playgroup. This study uses qualitative methods with a descriptive approach. Data collection techniques are observation, interview and documentation, while the data analysis technique is data triangulation technique. The results of research in the primagama padang creative kindergarden \& playgroup that brain gym activities have been carried out well, seen from semester planning, weekly and daily planning and evaluations carries out in every brain gymnastic activity. The implementation of brain gym activities provides many benefits to children.
\end{abstract}

Keywords: Brain Gym, Early Childhood, learning children

\begin{abstract}
Abstrak: Senam otak memiliki banyak manfaat terutama untuk menyeimbangi otak kiri dan kanan, melalui kegiatan senam otak dapat menumbuhkan semangat dan belajar anak. Penelitian ini menjelaskan kegiatan senam otak yang dilaksanakan di Taman Kanak-Kanak \& PlayGroup Kreatif Primagama Padang. Metode yang digunakan adalah kualitatif dengan pendekatan deskritif. Teknik pengumpulan data yaitu observasi, wawancara dan dokumentasi, sedangkan teknik analisis datanya adalah teknik triangulasi data. Hasil penelitian di Taman Kanak-Kanak \& PlayGroup Kreatif Primagama Padang bahwa kegiatan senam otak sudah terlaksana dengan baik, dilihat dari perencanaan semester, mingguan dan harian serta evaluasi yang dilakukan setiap kegiatan senam otak. Pelaksanaan kegiatan senam otak ini banyak memberikan manfaat kepada anak.
\end{abstract}

Kata Kunci: Senam Otak, Anak Usia Dini, Belajar Anak

\section{PENDAHULUAN}

Tahapan awal pada perkembangan manusia berada pada masa dini, dimana semua aspek berkembang sangaat baik. Maka di tahap ini dibutuhkan stimulasi yang tepat. Pertumbuhan dan perkembangan manusia sangat penting yaitu pada masa usia anak (Suryana, Pendidikan Anak Usia Dini, 2013). Usia dini merupakan masa awal dalam proses perrkembangan yang pesat untuk kehidupan berikutnya. Anak memiliki karakteristik sendiri yang membeda antara satu dengan yang lainnya (Yulsyofriend, 2013).

Melalui pendidikan dapat menyonsong potensi yang ada pada diri anak. Mulyasa menjelaskan anak usia dini mempunyai karakter tersendiri seperti, fisik, psikis, sosial, moral spiritual maupun emosional (Mulyasa, 2012). Pendidikan PAUD dibutuhkan anak dalam mengupayakan perkembangan. Susanto menjelaskan bahwa pendidikan anak usia dini merupakan suatu bentuk pembelajaran untuk memfokuskan dasar pertumbuhan yang tepat dan tahap perkembangan yang dilalui anak usia dini (Susanto, 2017). Suryana menjelaskan tujuan dari pendidikan anak usia dini membantu peletak dasar perkembangan sikap, perilaku, pengakuan, keterampilan, dan kreativitas yang diperlukan oleh anak (Suryana, Pendidikan Anak Usia Dini Stimulasi \& Aspek Perkembangan Anak, 2016). Berbagai media pembelajaran dan kegiatan yang dapat memberikan rangsangan terhadap perkembangan anak. Senam otak merupakan salah satu kegiatan yang dapat menstimulasi 
Jurnal PG-PAUD Trunojoyo : Jurnal Pendidikan dan Pembelajaran Anak Usia Dini, Volume 6,

terutama pada perkembangan kognitif, motorik, dan sosial emosional anak. Senam otak (Brain Gym) dipopulerkan oleh Paul E. Dennison, Dr Phill dengan istrinya Gail E. Dennison yang merupakan pelopor pendidikan di Amerika Serikat dalam penerapan senam otak.

Dennison \& Dennison (Priambodo, 2017) senam otak dapat mengimbangi antara otak yang berkaitan dengan fisik dan psikis. Kegiatan senam otak memiliki peran penting dalam pendidikan anak. Beberapa alasan pentingnya melaksanakan senam otak antara lain, sulit belajar nerusaha terlalu keras, sehingga membuat stress pada anak, kinerja integrasi otak melambat, dan membuat bagian otak tertentu kurang berfungsi dengan baik, bagian belakang otak menerima informasi sulit diekspresikan, membuat kurang fokus dan stress yang mengakibatkan semangat belajar berkurang, dan kurang belajar dan berusaha membuat prestasi menurun dan perasaan tidak berhasil semakin bertambah, akibatnya sulit untuk keluar dari lingkungan negatif tersebut (Sukri \& Sukri, 2013).

Berdasarkan penjabaran di atas serta awal pengamatan yang peneliti lakukan di Taman Kanak-kanak \& Playgroup kreatif primagama Padang, peneliti menemukan keunikan dari Taman Kanak-kanak yaitu memiliki rancangan kegiatan programprogram sendiri yang membedakan dari Taman Kanak-kanak pada umumnya seperti, berenang, fiel trip berdasa rkan tema, dan pelaksanaan kegiatan senam otak yang sudah terancang dengan baik. Peneliti memfokuskan penelitian pada senam otak karena Taman Kanak-kanak ini sudah menerapkan kegiatan senam otak sejak tahun 2008. Pelaksanaan kegiatan senam otak ini sudah terjadwal dalam perencanaan yaitu dilaksnakan pada hari selasa dan kami yang tertera dalam program rancangan pembelajaran harian (RPPH). Berdasarkan observasi tersebut peneliti tertarik untuk meneliti kegiatan senam otak di TK \& PlayGroup Kreatif Primagama Padang.

\section{METODE}

Pendekatan kualitatif dengan metode deskritif yang digunakan pada penelitian ini. Subjek penelitian ini adalah kelas TK B yang berjumlah 17 anak. Instrumen penelitian ini menggunakan format observasi, format wawancara dan format dokumentasi dengan informan penelitian yaitu kepala sekolah dan tiga guru kelas sebagai bukti bahwa peneliti telah melakukan pengamatan tentang kegiatan senam otak di Taman Kanak-kanak \& Play Group Kreatif Primagama Padang.

Melalui observasi, wawancara dan dokumentasi pada teknik pengumpulan data penelitian. Untuk pengumpulan data, reduksi data, penyajian data, dan verifikasi data yang digunakann dalam teknik analisis data. Sedangkan teknik keabsahan data yaitu triangulasi data. Triangulasi adalah teknik penyajian data dengan cara data yang disesuaikan dengan informan yang sama menggunakan teknik yang berbeda (Sugiyono, 2017). Dalam menguji kebenaran data mengenai pelaksanaan kegiatan senam otak di Taman Kanak-kanak \& PlayGroup Kreatif Primagama Padang, data yang sudah didapat dari lapangan disesuaikan dengan wawancara dan dokumentasi bersama kepala sekolah dan guru.

\section{HASIL DAN PEMBAHASAN}

\section{HASIL}

Dalam penelitian tentang kegiatan senam otak di Taman Kanak-kanak \& PlayGroup Kreatif Primagama Padang dapat disimpulkan bahwa kegiatan tersebut sudah terlaksana dengan baik yang disesuaikan dengan kemampuan anak. kegiatan senam otak terdapat 26 gerakan, 
namun guru memberikan pada anak sebanyak 15 gerakan, karena disesuaikan dengan kemampuan anak, Gerakan-gerakan tersebut mulai dari yang sederhana sampai tersulit. Adapun kegiatan senam otak dilaksanakan yaitu perencanan, pelaksanaan dengan tahapan-tahapan senam otak, gerakan-gerakan senam otak, manfaat kegiatan senam otak dan evaluasi.

Berdasarkan observasi, wawancara dan dokumentasi bahwa perencanaan kegiatan senam otak di Taman Kanakkanak \& Playgroup Kreatif Primagama Padang bahwa sudah memiliki perencanaan yang tertera dalam kurikulum, program semester, mingguan dan harian. Dalam perencanaan tersebut sudah muncul indikator-indikator pencapaian senam otak (Brain Gym) oleh anak.

\section{Tabel 1. Uraian Kegiatan di TK Kelompok B}

\section{A. Senin, Selasa, Rabu, Kamis \\ 1.Greeting (Penyambutan Siswa) (15 Menit) \\ 2. Iqro/mengenal Literasi (45 Menit) \\ 3. Opening (30 Menit) \\ $\checkmark$ Morning Carpet \\ $\checkmark$ Cirle Time \\ $\checkmark$ Brain Gym \\ 4.Focus Theme 1 (45 Menit) \\ 5. Take a Break (30 Menit) \\ 6. Snack Time (30 Menit) \\ 7. Focus Theme 2 (45 Menit) \\ 8. Review and Closing (15 Menit)}

B. Jumat

1.Greeting (Penyambutan Siswa) (15 Menit)

2. Iqro/Mengenal Literasi (45 Menit)

3. Opening (30 Menit)

$\checkmark$ Morning Carpet

$\checkmark$ Circle Time

4. Religious Activities (45 Menit)

5. Take a Break (15 Menit)

6. Snack Time (15 Menit)

7. Review and Closing (15 Menit)

8. Talents Class (45 Menit)

\section{Keterangan}

1. Hari Senin dan Rabu (Iqro)

2. Hari Selasa dan Kamis (Mengenal Literasi dan Brain Gym)
Pelaksanaan kegiatan brain gym pertama, tahapan-tahapan kegiatan senam otak di Taman Kanak-kanak \& PlayGroup Kreatif Primagama Padang. Berdasarkan observasi, wawancara dan dokumentasi kegiatan senam otak diawali dengan minum air putih, kemudian anak diminta untuk mangambil barisan dan ambil jarak agar tidak berdempetan dengan teman yang lain pada saat melakukan kegiatan senam otak. kedua pemanasan ringan dengan gerakangerakan sederhana, seperti pernafasan perut, geleng-geleng kepala, dan berdiri satu kaki untuk mengimbangi tubuh. Sebelum melakukan kegiatan senam otak guru menjelaskan kepada anak tujuan dilakukan senam otak tersebut yang membedakan dari kegiatan senam lainnya serta manfaat dan pentingnya untuk melakukan kegiatan senam otak (Brain Gym) tersebut.

Kedua, gerakan-gerakan senam otak (Brain Gym) memiliki gerakan sederhana dapat merangsang kemampuan otak kanan dan kiri anak. Observasi yang dilakukan di TK \& PlayGroup Kreatif Primagama dalam kegiatan senam otak terdapat gerakan-gerakan yang termasuk dalam dimensi lateral pertama, gerakan silang dimana gerakannya untuk menggerakan organ tubuh kiri dan kanan secara bersamaan. Kedua, gajah dimana gerakan yang menyerupai belalai gajah dengan menyilangkan tangan kanan dan kiri, satu tangan memegang hidung dan satunya lagi memegang telinga dan dilakukan secara bergantian antara kiri dan kanan. Selanjutnya gerakan-gerakan yang termasuk dalam dimensi pemfokusan pertama lambaian tangan dengan tangan keatas berada pada samping telinga kemudian tangan kedua di siku bawah yang berguna untuk meregangkan ketegangan di otot pundak, mengontrol koordinasi mata dan tangan. Selanjutnya dimensi pemusatan yaitu, minum air putih yang bertujuan mempermudah pengaliran energy dari otak ke seluruh tubuh. pompa betis, luncuran gravitasi, dan pasang kuda-kuda. Adapun 
gerakan-gerakan lainnya sudah disesuaikan dengan kemampuan anak.

Ketiga, manfaat kegiatan senam otak untuk anak. berdasarkan observasi, wawancara dan dokumentasi, manfaat senam otak terutama pada anak sangat banyak. Pada pembelajaran anak lebih tenang belajar, lebih semangat, meningkatkan konsetrasi dalam belajar dan meningkatkan daya ingat anak, hal ini dapat dilihat ketika selesai belajar dan melakukan tanya jawab tentang pembelajaran yang sudah dipelajari hari ini, jika anak bisa menjawab angat tangan. Dan hampir semua anak mengankat tangan.

Kemudian evaluasi, berdasarkan hasil temuan yang di dapatkan dari hasil observasi, wawancara dan dokumentasi oleh peneliti serta berdasarkan analisis data yang peneliti lakukan tentang perencanaan kegiatan senam otak (Brain Gym) di Taman Kanak-kanak \& PlayGroup Kreatif Primagama Padang yaitu kurikulum, proses perencanaan kegiatan untuk semester (Semester Plan) dan rencana pembelajaran mingguan (Weekly Plan/RPPM) dan rencana pelaksanan pembelajaran harian (Lesson Plan/RPPH). Rancangan kegiatan harian dibagi menjadi Opening, Fokus Theme dan Closing. Pembuatan perencanaan kegiatan senam otak (Brain Gym) sesuai dengan kebutuhan anak. Kegiatan yang dilaksanakan berdasarkan jadwal kegiatan yang sudah dirancang. Tersusunnya dokumen yang dijadikan sebagai acuan dan pedoman dalam melaksnakan proses pembelajaran merupakan hasil akhir dari proses pengambilan keputusan tersebut.

\section{PEMBAHASAN}

Hasil penelitian tentang kegiatan senam otak anak usia dini di Taman Kanakkanak \& Playgroup Kreatif Primagama Padang akan dibahas berdasarkan teori, sehinggaa akan terlihat keterkaitan antara teori dengan fakta yang ada dilapangan.
Belikut pembahasan dari hasil penelitian di atas :

Perencanaan, berdasarkan hasil temuan yang di dapatkan melalui observasi, wawancara dan dokumentasi yang dilakukan peneliti serta berdasrakan analisis data yang peneliti lakukan tentang perencanaan kegiatan senam otak di Taman Kanak-kanak \& Playgroup Kreatif Primagama Padang dimulai dari program tahunan, proses perencanaan kegiatan semester, mingguan dan harian. Rancangan kegiatan harian terbagi menjadi Opening, Focus Theme, dan Closing. Pembuatan perencanaan kegiatan senam otak sesuai dengan kebutuhan anak. kegiatan yang dilaksanakan disesuaikan berdasrkan jadwal kegiatan yang dirancang. Proses pengambilan keputusan pada hasil akhir yang tersusunnya dokumen yang berisi tentang hal tersebut, kemudian dijadikan sebagai acuan dan pedoman dalam melaksanakan proses pembelajaran.

Pelaksanaan kegiatan senam otak pertama, tahapan-tahapan kegiatan senam otak. berdasarakan hasil temuan di lapangan, wawancara dan dokumentasi yang dilakukan peneliti serta analisis data yang peneliti lakukan diperoleh hasil bahwa kegiatan senam otak telah sesuai dnegan perencanaan yang telah dirancang oleh guru. Adapun sebelum melakukan kegiatan senam otak terdapat tahapan-tahapan dilakukan seperti secukupnya minum air putih, yang bertujuan untuk menetralisirkan dan memberikan oksigen ke otak sehingga memudahkan dalam melaksanakan kegiatan senam otak. Selanjutnya pemanasan sederhana, hal ini bertujuan untuk menghindari cedera pada otot-otot. Pemanasan sederhana yang baik untuk anak, seperti pernafasan perut sebanyak delapan kali dilanjutkan gerakan-gerakan sederhana. Hal ini sesuai dengan pendapat Sulis Diana dkk dalam melakukan kegiatan senam otak ada beberapa yang perlu dilakukan yaitu, minum air putih dan pernafasan perut sebanyak 2-8 kali (Diana \& dkk, 2017). 
Kedua, gerakan senam otak. Berdasarkan temuan di Taman Kanakkanak \& Plagroup Kreatif Primagama Padang bahwa gerakan senam otak yang dilakukan disesuaikan dengan kemampuan anak. Adapun gerakan-gerakannya sebanyak 15 gerakan yang diiringi musik. Terdapat tiga dimensi dalam gerakan senam otak yaitu dimensi lateral, dimensi pemfokusan dan dimensi pemusatan. Menurut Paul Dennison "senam otak dilakukan melalui tida dimensi, yakni dimensi lateral, dimensi pemusatan dan dimensi pemfokusan". Gerakan-gerakan lebih berpusat pada tangan, seperti jari kanan gerakan gajah dimana tangan kiri memegang telinga dan tangan kanan memegang hidung, bayangankan tangan menjadi belalai gajah, ikuti 8 tidur yang terletak agak jauh yang bertujuan untuk meningkatkan penglihatan, pendengaran dan gerakan seluruh tubuh, lambaian tangan dimana letakkan kuda dibawah siku lewat belakang kepala. Leher di putar dimana bahu dinaikkan, tundukan kepala ke depan dan putar dari satu sisi ke sisi lainnya. Putaran kepala, gelengkan kepala, putaran tangan. Semua gerakan termasuk dalam tiga dimensi, namun selebihnya gerakan di fariasikan oleh guru sesuai dengan iringan musik. Dalam kegiatan senam otak diiringi musik sehingga anak lebih semangat dalam kegiatan senam otak.

Ketiga,manfaat senam otak. berdasarkan temuan di Taman Kanak-kanak \& Playgroup Kreatif Primagam Padang bahwa manfaat kegiatan senam otak sudah terlihat pada diri anak, dibuktikan dalam proses pembelajaran anak dapat menjawab dan mengulangi kembali pembelajaran yang dipelajari hampir semua anak dapat menjawab pertanyaan yang di ajukan oleh guru. Kusuma menjelaskan dengan sering melakukan senam otak dapat meningkatkan pertumbuhan sel-sel otak, menyimpan memori dan meningkatkan fokus dalam belajar. Dilihat dari perkembangan emosional, dimana dalam proses suasana belajar anak terlihat tenang dan senang.
Disamping itu anak tidak berebutan dalam mengambil media pembelajaran, dan sudah bisa mempratekan sifat antri dengan baik tanpa harus mendahulukan satu dengan yang lain. Sejalan dengan pendapat Zulaini menjelaskan manfaat senam otak seperti meningkatkan konsentrasi, mengurangi stress, meningkatkan daya ingat, dapat berfikir lebih cepat, pelajar dapat menangkap pelajaran dengan baik (Zulaini, 2016). Hal ini senada dengan Dennison (Priambodo, 2017) menjelaskan bahwa ada beberapa manfaat senam otak yaitu memberikan stumulus pada kegiatan belajar dan efektif dalam mengalami hambatan belajar, dan memudahkan siswa untuk berfikir, merefleksikan suatu pekerjaan/tugas atau karya.

Evaluasi kegiatan senam otak di

Taman Kanak-kanak \& Playgroup Kreatif Primagama berdasarkan hasil temuan penelitian, peneliti melihat guru mengevaluasi kegiatan melalui observasi yaitu dengan melihat proses anak melaksanakan kegiatan senam otak. Evaluasi kegiatan disesuaikan dengan perencanaan yang sudah dikembangkan.

\section{SIMPULAN}

Berdasarkan hasil penelitian tentang kegiatan senan otak anak usia dini di Taman Kanak-kanak \& Playgroup Kreatif Primagama Padang dapat disimpulkan bahwa kegiatan senam otak dilaksanakan dengan baik. Kegiatan senam otak melalui perencanaan yang dirancang oleh guru sehingga terjadwal dengan baik. Senam otak dilakukan dalam bentuk gerakan-gerakan sederhana yang dapat merangsang perkembangan otak, meningkatkan konsetrasi dalam belajar. Evaluasi kegiatan senam otak yang dilakukan guru melalui observasi yaitu melihat proses anak dalam melakukan kegiatan senam otak. 
Jurnal PG-PAUD Trunojoyo : Jurnal Pendidikan dan Pembelajaran Anak Usia Dini, Volume 6,

Nomor 1, April 2019, hal 12 - 17

\section{DAFTAR PUSTAKA}

Diana, S., \& dkk. (2017). Brain Gym Stimulasi Perkembangan Anak Paud I. Surakarta: CV Kekata Group.

Mulyasa. (2012). Manajemen PAUD. Bandung: Remaja Rosdakarya.

Priambodo, M. (2017). Brain Gym. Retrieved from http://www.brain\%gym/78032541.pdf

Sugiyono. (2017). Metode Penelitian Pendidikan Pendekatan Kuantitatif, Kualitatif dan R\&D. Bandung: Alfabeta.

Sukri, A., \& Sukri, P. (2013). Meningkatkan Hasil Belajar Siswa Melalui Brain Gym. Jurnal Edukasi Matematika dan Sains.

Suryana, D. (2013). Pendidikan Anak Usia Dini. Padang: UNP Press.

Suryana, D. (2016). Pendidikan Anak Usia Dini Stimulasi \& Aspek Perkembangan Anak. Jakarta: PT Raja Grafindo Persada.

Susanto, A. (2017). Pendidikan Anak Usia Dini. Jakarta: PT Bumi Aksara.

Yulsyofriend. (2013). Permainan Membaca dan Menulis Anak Usia Dini. Padang: Sukabina Press.

Zulaini. (2016). Manfaat Senam Otak. Retrieved from http://www.6140-12223-1-PB.pdf 